\title{
Sustainability assessment and physical characterization of pervious concrete pavement made with GGBS
}

\author{
Hilal El-Hassan ${ }^{1, *}$ and Peiman Kianmehr ${ }^{2}$ \\ ${ }^{1}$ Department of Civil and Environmental Engineering, United Arab Emirates University, Al \\ Ain, United Arab Emirates, P.O. Box 15551 \\ ${ }^{2}$ Department of Civil Engineering, American University in Dubai, Dubai, United Arab \\ Emirates, P.O. Box 28282
}

\begin{abstract}
The increasing use of pervious concrete as sustainable and environment-friendly paving materials is primarily owed to its ability to reduce pavement runoff. The mechanical and transport properties of pervious concrete with $50 \%$ ground-granulated blast furnace slag (GGBS) replacement are examined in this paper. Open-graded $10 \mathrm{~mm}$ and $20 \mathrm{~mm}$ aggregates were used to attain porosity of $10 \%, 15 \%$, and $20 \%$. Polypropylene short cut fibers were added to the mix. The clogging potential of pervious concrete exposed to dust was also investigated. The results indicated that increasing the porosity led to a decrease in compressive and tensile strength. Similar findings were reported when smaller aggregates were used. The fiber addition was only effective in low-porosity concrete. Permeability, characterized by its coefficient k, was proportional to porosity and inversely proportional to aggregate size. After 40-year simulated dust exposure, the concrete permeability could be restored with water flushing maintenance process. In comparison to ordinary Portland cement (OPC) concrete, pervious concrete incorporating GGBS is a more sustainable paving solution, offering a reduction in heat island effect and electricity consumption while also alleviating carbon emissions.
\end{abstract}

\section{Introduction}

Porous or pervious pavements have been recommended by the U.S. Environmental Protection Agency (EPA) and the U.S. Green Buildings Council (USGBC) as sustainable alternatives for the current paving systems [1]. A typical cross-sectional schematic of pervious concrete pavement is presented in Figure 1. Past research described five main advantages for employing pervious pavements compared to traditional dense pavements. It permits natural water treatment with an increased retention time before discharging it into the ecosystem, reduces the demand for storm water collection systems, reduces energy consumption by nearly $20 \%$, increases skid resistance and replenishes ground water aquifers below the pavement $[2,3]$. Additionally, their use could lessen the glare on road surfaces,

\footnotetext{
*Corresponding author: helhassan@uaeu.ac.ae
} 
decrease tire-pavement noise, preserve natural resources, and reduce lifecycle maintenance costs [4].

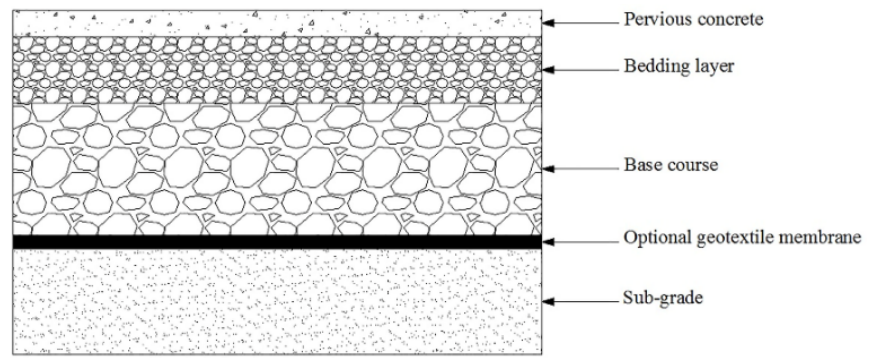

Fig. 1. Typical cross-sectional schematic of pervious concrete pavement [5].

The main benefit of employing pervious pavements in some applications is eliminating storm water collection systems by replenishing pavement runoff. In areas experiencing blockage in roadway drainage, such as the United Arab Emirates (UAE), this would be especially valuable. In the UAE, heavy rain occurs, on average, four times per year as per precipitation charts from 2010-2012 [6], inducing excessive traffic disturbances, road overflowing, car accidents, economic losses, and life causalities [7]. It is estimated that traffic incidents, including those due to rain, caused more than 2.9 billion Dirhams (AED) of losses on Dubai's economy during the year of 2013 and would incur more than 4 billion AED during the year of 2020 [8].

Studies have shown that concrete is the most environment-friendly and efficient road material despite the fact that most roadways are asphaltic [9]. Pervious concrete is different than ordinary concrete in that it includes no fine aggregates, has a void content between 15 and $25 \%$, and experiences compressive strengths of 2.8 to $28 \mathrm{MPa}$ [10]. From an economic standpoint, the Portland Cement Association (PCA) reported that concrete is in fact cheaper than asphalt based on initial and lifecycle maintenance costs given its superior durability [11]. Others noted $30 \%$ savings in initial, energy, and maintenance costs, and 8 to $9 \%$ reduction in carbon dioxide emissions [12]. With a higher albedo value, concrete is able to reduce electricity and lighting consumption while also decreasing the heat island effect of compared to asphaltic pavement [1,9]. A study by National Resources Council of Canada showed $0.8 \%$ to $6.9 \%$ in fuel savings and associated $\mathrm{CO}_{2}$ emissions per $100 \mathrm{~km}$ roadway $[13,14]$. Furthermore, $1 \mathrm{~km}$ of high volume roadway paved with conventional concrete produced 674 tons of $\mathrm{CO}_{2}$, while asphalt concrete generated 738 tons [15].

This paper aims to investigate the potential use of self-draining pervious concrete pavements in the UAE as a mechanism counter the societal and economic consequences of rainwater runoff. Ordinary Portland Cement $(\mathrm{OPC})$ and ground-granulated blast furnace slag (GGBS) with 1:1 ratio by mass are used to cast 9 concrete mixes. GGBS, a byproduct of iron and steel making industry, is utilized as a sustainable cement replacement to reduce the carbon footprint while providing a brighter and improved surface finish to so-produced concrete. Based on previous studies, fibers are also added to improve mechanical performance of pervious concrete [16]. The objective is to optimize mechanical and transport properties with various concrete mixture proportions. A simulation over the 40 -year lifespan of concrete is carried out to study its clogging potential in the UAE's desert-dominant terrain. Analyses of embodied energy and carbon footprint are also conducted to compare pervious concretes with a $100 \%$ OPC concrete. 


\section{Materials and methods}

\subsection{Sample preparation}

Pervious concrete mixes incorporated ASTM Type I ordinary Portland cement (OPC), ground granulated blast-furnace slag (GGBS), $10 \mathrm{~mm}$ and $20 \mathrm{~mm}$ aggregates, and Asota $\mathrm{MCP} / \mathrm{AFC} 18$ fibers (micro crack preventer/anti fire crack). The chemical composition and physical properties of cement and GGBS are given in Table 1 and 2, respectively. Figure 2 shows the particle size distribution of aggregates following ASTM C136 [17]. The mixing constituents were maintained at room temperature $\left(22 \pm 1^{\circ} \mathrm{C}\right)$ prior to mixing, according to ASTM C192 [18]. After mixing in a drum mixer, fresh concrete was cast into 150 x $300 \mathrm{~mm}$ cylinders. The obtained specimens were demolded after 24 hours and then water-cured in a tank at $23 \pm 1^{\circ} \mathrm{C}$ until testing.

Table 1. Chemical composition of cement and GGBS.

\begin{tabular}{|c|c|c|c|c|c|c|c|c|}
\hline & \multicolumn{7}{|c|}{ Chemical composition (\%) } \\
\cline { 2 - 9 } Material & $\mathbf{C a O}$ & $\mathbf{S i O}_{2}$ & $\mathbf{A l}_{\mathbf{2}} \mathbf{O}_{3}$ & $\mathbf{F e}_{2} \mathbf{O}_{3}$ & $\mathbf{M g O}$ & $\mathbf{N a O}$ & $\mathbf{S O}_{3}$ & $\mathbf{L O I}$ \\
\hline Cement & 63.2 & 19.9 & 4.9 & 2.3 & 2.5 & 0.8 & 3.8 & 2.6 \\
\hline GGBS & 42.1 & 35.4 & 10.6 & 0.4 & 8.1 & - & 0.3 & 3.1 \\
\hline
\end{tabular}

Table 2. Physical properties of cement and GGBS.

\begin{tabular}{|c|c|c|}
\hline \multirow{2}{*}{ Material } & \multicolumn{2}{|c|}{ Physical properties } \\
\cline { 2 - 3 } & $\begin{array}{c}\text { Specific } \\
\text { gravity }\end{array}$ & $\begin{array}{c}\text { Surface } \\
\text { area }\left(\mathbf{c m}^{2} / \mathbf{g}\right)\end{array}$ \\
\hline Cement & 3.14 & 3670 \\
\hline GGBS & 2.90 & 4550 \\
\hline
\end{tabular}

ACI 522R-10 was followed in proportioning the concrete mixes [4]. The mix design for 9 concrete batches are summarized in Table 3. Each mix was labeled based on the size of aggregates used and porosity; for instance, $\mathrm{C} / 10 / 20$ was made with $10 \mathrm{~mm}$ aggregate and had a porosity of $20 \%$. A control batch (Ref-OPC) was prepared with $10 \%$ porosity, $10 \mathrm{~mm}$ aggregates, and OPC as binder. The concrete's experimental porosity was compared to its design value as per Equation 1 [19].

$$
\text { Experimental Porosity }(\%)=\left[1-\left(\frac{\text { Oven-dried Weight }(\mathrm{kg})-\text { Submerged Weight }(\mathrm{kg})}{\text { Sample Volume }\left(\mathrm{m}^{3}\right) . \text { Density of Water }\left(\mathrm{kg} \mathrm{m}^{-3}\right)}\right)\right] 100 \%
$$

The amount of aggregate and water-to-cementitious material $(\mathrm{w} / \mathrm{cm})$ ratio was fixed to $1833.6 \mathrm{~kg} / \mathrm{m}^{3}$ and 0.30 , respectively, whereas the cementitious material content was reduced to increase the porosity. In all mixes, the cementitious binder incorporated cement and GGBS at a $1: 1$ ratio. The density of the hardened concretes ranged between $2030 \mathrm{~kg} / \mathrm{m}^{3}$ and 2275 $\mathrm{kg} / \mathrm{m}^{3}$ compared to $2359 \mathrm{~kg} / \mathrm{m}^{3}$ for the controlled reference. Similar values have been reported in other work [20]. For $1 \mathrm{~m}^{3}$ of concrete, $0.6 \mathrm{~kg}$ of $18 \mathrm{~mm}$ polypropylene short cut fibers were added. The resulting concretes were labeled, for example, C/10/20/f. The mixes were designed to study the effect of aggregate size, porosity and fibers addition on mechanical and transport properties. 


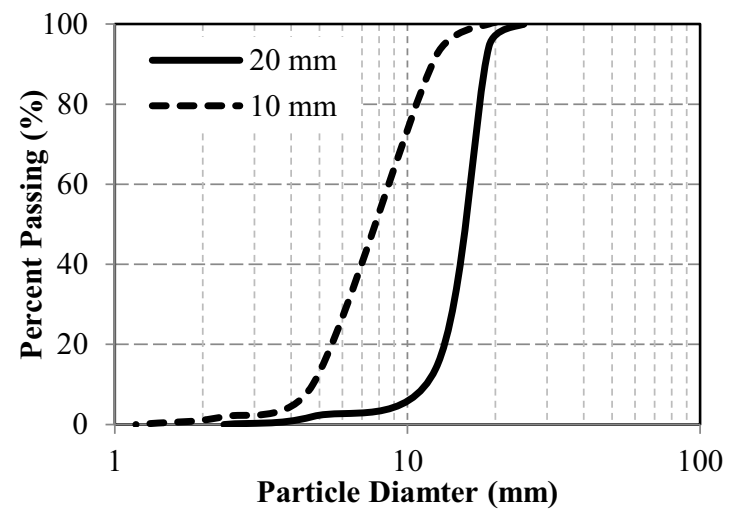

Fig. 2. Particle size distribution of aggregates.

Table 3. Mix design of pervious concretes

\begin{tabular}{|c|c|c|c|c|c|c|c|c|c|}
\hline \multirow[b]{2}{*}{ Sample } & \multicolumn{2}{|c|}{ Aggregate $\left(\mathrm{kg} / \mathrm{m}^{3}\right)$} & \multicolumn{3}{|c|}{ Cementitious Material $\left(\mathrm{kg} / \mathrm{m}^{3}\right)$} & \multirow{2}{*}{$\begin{array}{l}\text { Water } \\
\left(\mathrm{kg} / \mathrm{m}^{3}\right)\end{array}$} & \multirow{2}{*}{$\begin{array}{l}\text { Fibers } \\
\left(\mathrm{kg} / \mathrm{m}^{3}\right)\end{array}$} & \multirow{2}{*}{$\begin{array}{c}\text { Porosity } \\
\text { (\%) }\end{array}$} & \multirow{2}{*}{$\begin{array}{l}\text { Density } \\
\left(\mathrm{kg} / \mathrm{m}^{3}\right)\end{array}$} \\
\hline & $10 \mathrm{~mm}$ & $20 \mathrm{~mm}$ & OPC & GGBS & Total & & & & \\
\hline $\mathrm{C} / 10 / 10$ & 1833.6 & 0.0 & 192.6 & 192.6 & 385.2 & 115.5 & 0.0 & 10.0 & 2191.8 \\
\hline $\mathrm{C} / 10 / 10 / \mathrm{f}$ & 1833.6 & 0.0 & 192.6 & 192.6 & 385.2 & 115.5 & 0.6 & 10.0 & 2200.2 \\
\hline $\mathrm{C} / 10 / 15$ & 1833.6 & 0.0 & 185.2 & 185.2 & 370.4 & 111.1 & 0.0 & 15.0 & 2100.4 \\
\hline $\mathrm{C} / 10 / 15 / \mathrm{f}$ & 1833.6 & 0.0 & 185.2 & 185.2 & 370.4 & 111.1 & 0.6 & 15.0 & 2105.2 \\
\hline $\mathrm{C} / 10 / 20$ & 1833.6 & 0.0 & 178.0 & 178.0 & 355.9 & 106.8 & 0.0 & 20.0 & 2036.3 \\
\hline $\mathrm{C} / 10 / 20 / \mathrm{f}$ & 1833.6 & 0.0 & 178.0 & 178.0 & 355.9 & 106.8 & 0.6 & 20.0 & 2040.1 \\
\hline $\mathrm{C} / 20 / 10$ & 0.0 & 1833.6 & 200.1 & 200.1 & 400.1 & 120.0 & 0.0 & 10.0 & 2259.1 \\
\hline $\mathrm{C} / 20 / 10 / \mathrm{f}$ & 0.0 & 1833.6 & 200.1 & 200.1 & 400.1 & 120.0 & 0.6 & 10.0 & 2261.5 \\
\hline Ref-OPC & 1833.6 & 0.0 & 420.1 & 0.0 & 420.1 & 126.0 & 0.0 & 10.0 & 2359.3 \\
\hline
\end{tabular}

\subsection{Performance evaluation}

\subsubsection{Mechanical testing}

Pervious concrete specimens were removed from the water curing tank and maintained in a moist condition up to mechanical testing. In accordance with ASTM C39, the 7 and 28-day compressive strength was measured [21]. The splitting tensile strength of cylindrical concrete samples was determined after 28 days following ASTM C496 [22]. For each experiment, three replicate cylinders per batch were tested to obtain an average.

\subsubsection{Falling head permeability test}

The permeability coefficient, $\mathrm{k}$, represents the permeability of concrete. It is the amount of fluid passing through a unit area per unit time under a unit hydraulic gradient. As specified by ACI 522R-10, the falling head apparatus (see Figure 3) was used to estimate the permeability of pervious concrete [4]. While the mechanism remains the same in major investigations, the procedure is often modified depending on the type of experimentation. A graduated plastic pipe of cross-sectional area $A_{p}\left(\mathrm{~m}^{2}\right)$ was attached to the top cap of the vessel. The concrete cylinders with cross-sectional area $A_{c}\left(\mathrm{~m}^{2}\right)$ were supported halfway through the 
vessel. The samples employed in this test were sealed around the circumference with epoxy mortar to maintain an axial water flow without lateral leakage [23]. As the water level dropped from a height $h_{0}(\mathrm{~m})$ to $h_{l}(\mathrm{~m})$, it passed a distance, $L(\mathrm{~m})$, in time, $t(\mathrm{~s})$. For each concrete batch, three replicate cylinders were tested and averaged. Darcy's law, given by Equation 2, was used to calculate the permeability coefficient, $\mathrm{k}(\mathrm{m} / \mathrm{s})$ [24]:

$$
k=\frac{A_{p} L}{A_{c} t} \ln \left(\frac{h_{0}}{h_{l}}\right)
$$

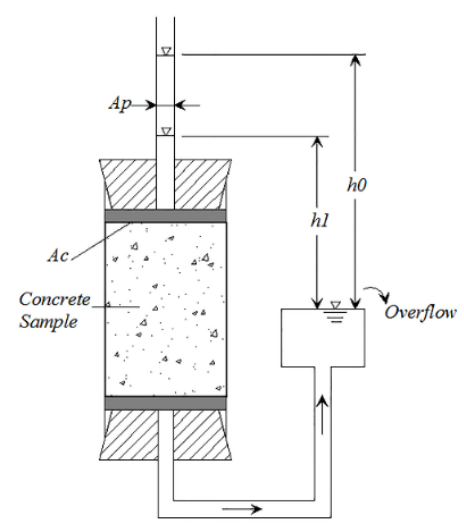

Fig. 3. Falling head permeability apparatus [5].

\subsubsection{Dust clogging test}

The service life of pervious pavements is majorly affected by the clogging due to dust exposure [25]. Recently, a study showed that, on average, dust deposited and accumulated at $9.34 \mathrm{~g} / \mathrm{m}^{2}$.day and peaked at $21.31 \mathrm{~g} / \mathrm{m}^{2}$.day [26]. The dust used in this study was collected an urban area in Dubai. Sieve analysis was employed to obtain the particle size distribution, shown in Figure 4. The falling head apparatus was modified to examine the clogging potential of the various concrete mixes. To simulate rain activity in dusty weather, a shower head was installed in the vessel cap and a mixture of water and dust, proportioned based on the reported accumulations, surged through. The permeability coefficient was then recorded over a 40year simulation representing pavement service life.

\subsubsection{Albedo test}

Albedo values represent the ratio of reflective to incident light discharged onto a surface. According to study by Kaloush et al., weathered and new asphalt pavement had an albedo ranging between 0.05 and 0.15 [27]. On the other hand, concrete made with ordinary Portland cement (OPC) had an albedo value in the range of 0.20 and 0.40 [27]. Apparently, brighter material resulted in higher albedo and a reduction in heat island effect. Additionally, replacing dark asphalt pavements with concrete pavements showed a reduction in electricity demand and lighting costs by nearly $30 \%[3,9]$. To measure the albedo of pervious concrete specimens, a digital camera was paired with a software package to obtain the luminance value and Red/Green/Blue (RGB) histogram of a selected area. They are then used to determine the albedo value. 


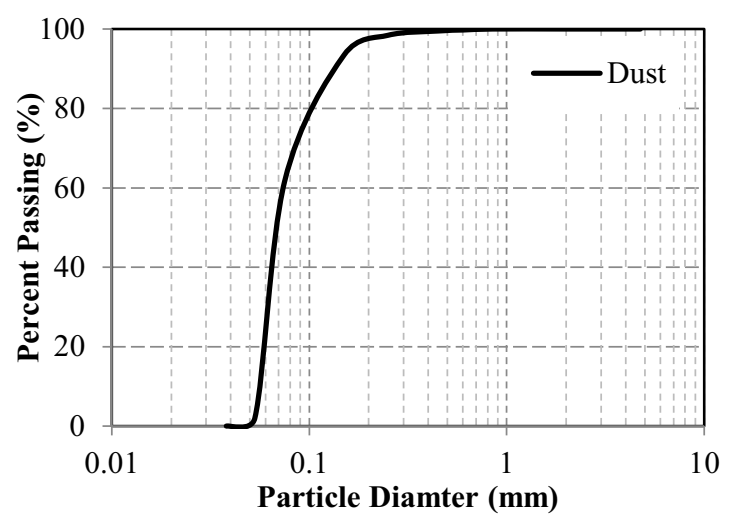

Fig. 4. Particle size distribution of dust.

\section{Results and discussion}

\subsection{Compressive and splitting tensile strength}

The 7-day compressive strength results are presented in Figure 5. By comparing batches $\mathrm{C} / 10 / 10, \mathrm{C} / 10 / 15$ and $\mathrm{C} / 10 / 20$, the effect of porosity on compressive strength was assessed with constant aggregate size of $10 \mathrm{~mm}$. The aggregate-to-cementitious material $(\mathrm{A} / \mathrm{CM})$ ratio was increased to produce a more pervious or porous concrete. As a result, the compressive strength was reduced due to more voids and lesser hydration products. Another comparison of the 7-day compressive strength concrete $\mathrm{C} / 10 / 10$ and $\mathrm{C} / 20 / 10$ investigated the effect of aggregate size. Typically, concretes made with open-graded aggregates produce more voids if a larger particle size is used [9]. In fact, to maintain a porosity of $10 \%$, more cementitious material was used in $20 \mathrm{~mm}$ mixes compared to $10 \mathrm{~mm}$ counterparts. It was clear that concrete with $20 \mathrm{~mm}$ aggregates experienced higher compressive strength owing to the higher cementitious material content and, as a result, more hydration products. In addition, the effect of adding Asota MCP/AFC 18 fibers to concrete is studied after 7 days in Figure 5. While their addition seemed to improve strength in concretes with $10 \%$ porosity, it reduced the mechanical performance for $15 \%$ and $20 \%$ samples. Apparently, the fibers utilized in this work could only increase compressive strength of concrete with low porosity $(10 \%)$.

After 28-day subsequent hydration, concrete specimens presented higher compressive strength. Mechanical performance of concretes with $10 \%$ porosity and $20 \mathrm{~mm}$ aggregates was superior to other samples at $54 \mathrm{MPa}$. It is much higher than the minimum 28-day strength required by the Virginia Department of Transportation (VDOT) of $20.7 \mathrm{MPa}$ [28]. With 15 $\mathrm{MPa}$, concrete $\mathrm{C} / 10 / 20 / \mathrm{f}$ was considered inadequate for dense roadways but could be recommended for areas of low traffic congestion such as local roads, parking lots and road shoulders.

Figure 5 also shows the splitting tensile strength after 28 days. With $10 \mathrm{~mm}$ aggregates, an increase in the porosity of concrete from $10 \%$ to $20 \%$ led to a $24 \%$ decrease in tensile strength. Changing the aggregate size from $10 \mathrm{~mm}$ to $20 \mathrm{~mm}$, however, resulted in an increase in tensile strength by $25 \%$. The addition of fibers did not significantly enhance the tensile strength. While the length of the fibers possibly rendered them ineffective in the produced pores, it is apparent that porosity was the major governing factor. Similar results have been noted in other studies on pervious concrete [29]. 


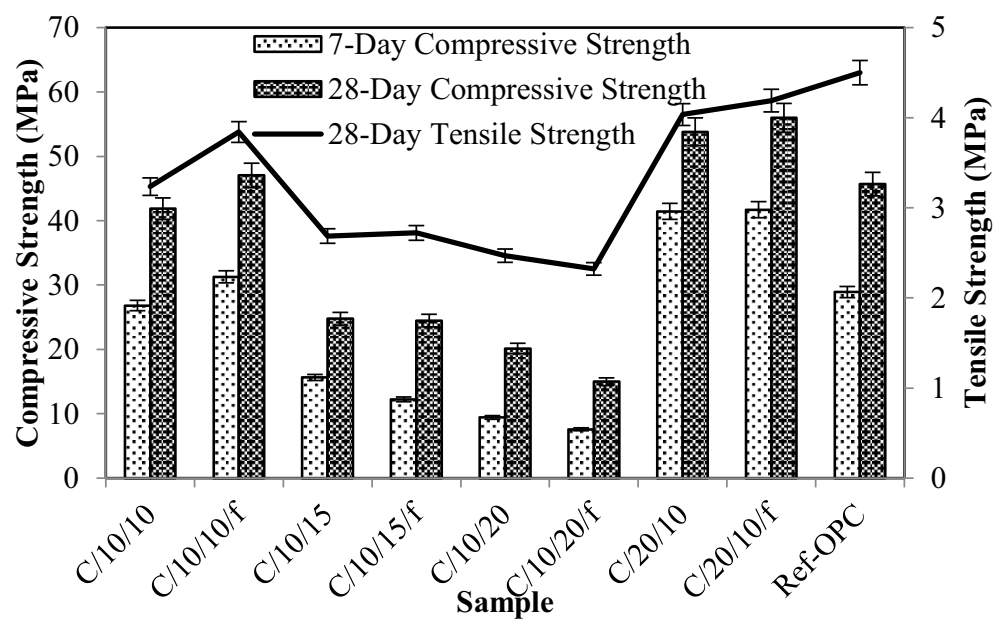

Fig. 5. Compressive and tensile strength of concrete samples.

\subsection{Permeability}

The permeability of pervious concrete was investigated through its coefficient, $\mathrm{k}$. The falling head apparatus and Equation 2 were collectively used to determine the experimental values of $\mathrm{k}$, presented in Table 4 . The results show a proportional relation between permeability and porosity, as has also been reported in other work [19, 29]. The lower cementitious material content in concretes incorporating 50\% GGBS resulted in a higher permeability compared to the control sample. Larger aggregates required more CM and, consequently, led to a less dense concrete with a lower $\mathrm{k}$ value. Furthermore, the addition of fibers seemed to have decreased the permeability by occupying empty space in the concrete structure. To better explain the experimental values, an area of $1 \mathrm{~m}^{2}$ is considered across which water is drained. The resulting permeability for $\mathrm{C} / 20 / 10$ of $1.8 \mathrm{~mm} / \mathrm{s}$ is equivalent to draining $1.8 \mathrm{~L}$ of water per second or $108 \mathrm{~L}$ per minute.

\subsection{Dust clogging}

Based on the mechanical and transport properties, concrete $C / 20 / 10$ was selected to evaluate its potential use as pervious concrete pavement on the roads of the UAE. Samples were exposed to dust for a 40 -year simulation of the concrete lifespan. Dust was chosen as it is finer than sand, could lead to further transportation into the concrete, and could cause a more noticeable reduction in the value of $\mathrm{k}$ [30]. As such, the effect of dust exposure on the permeability of pervious concrete was investigated following the accumulation reported by Hamza [26]. The results, depicted in Figure 6, present a continuous decrease in the permeability coefficient over 40 years.

A maintenance procedure was proposed by water flushing the concrete specimens after 12 years of simulated exposure. While the initial permeability was $1.8 \mathrm{~mm} / \mathrm{s}$, it could be restored to $1.69,1.45$, and $1.2 \mathrm{~mm} / \mathrm{s}$ due to subsequent maintenance at 12,24 , and 36 years, respectively. Accordingly, a $67 \%$ recovery of $\mathrm{k}$ was recorded after 36 years, indicating that water flushing or cleansing could recycle the concrete while disposing of clogging dust particles. It is possible that surface clogging, as noted by visual inspection, could be responsible for the reduction in permeability. In fact, it is for this reason that cleaning the surface with water was effective in partially restoring the permeability. 
Table 4. Permeability coefficient of concrete mixes.

\begin{tabular}{|c|c|}
\hline Sample & $\begin{array}{c}\text { Permeability } \\
\text { coefficient, } \mathbf{k}(\mathbf{m m} / \mathbf{s})\end{array}$ \\
\hline $\mathrm{C} / 10 / 10$ & $1.94 \pm 0.18$ \\
\hline $\mathrm{C} / 10 / 15$ & $2.50 \pm 0.21$ \\
\hline $\mathrm{C} / 10 / 20$ & $7.50 \pm 0.74$ \\
\hline $\mathrm{C} / 10 / 20 / \mathrm{f}$ & $7.22 \pm 0.79$ \\
\hline $\mathrm{C} / 20 / 10$ & $1.80 \pm 0.19$ \\
\hline Ref-OPC & $1.58 \pm 0.29$ \\
\hline
\end{tabular}

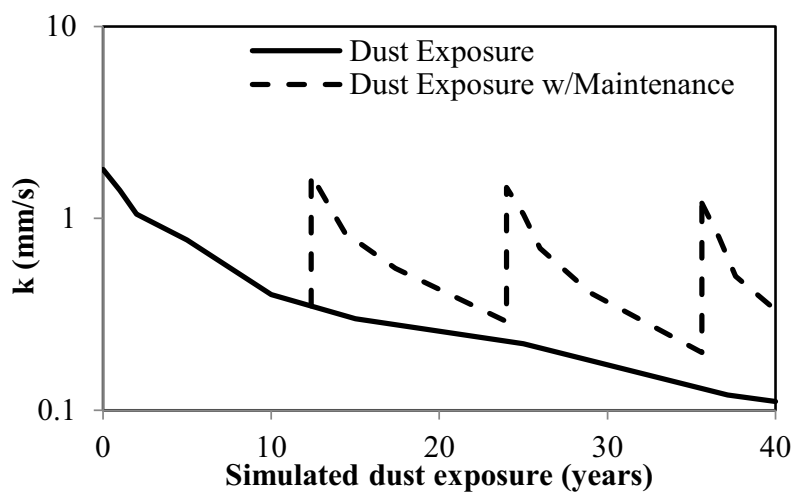

Fig. 6. Dust clogging test of concrete $\mathrm{C} / 20 / 10$ [5].

\subsection{Albedo values}

The albedo values of different materials are summarized in Table 5. A white paper had an albedo value of 0.60 and served as a reference. The sustainable concrete mixes with $50 \%$ GGBS presented an albedo of 0.52 , while that of the reference made with $100 \%$ OPC was 0.40 . Other work on OPC concrete reported a value of 0.45 [27]. It seemed that incorporating GGBS, which had an off-white color, contributed to a brighter surface finish of the pervious concrete. If such lighter-colored concrete is used in UAE cities, it could aid in reducing the reported $6^{\circ} \mathrm{C}$ heat island effect [31].

Table 5. Albedo values of different paving materials.

\begin{tabular}{|c|c|}
\hline Material & Albedo Value \\
\hline Asphalt [27] & 0.10 \\
\hline OPC Concrete [27] & 0.45 \\
\hline OPC+GGBS Concrete & 0.52 \\
\hline Ref-OPC & 0.40 \\
\hline White Paper & 0.60 \\
\hline
\end{tabular}




\subsection{Embodied energy, carbon footprint and cost analysis}

The embodied energy and carbon dioxide emissions of pervious concretes are presented in Figure 7. OPC, GGBS, aggregates and fibers have respective embodied energies of 5.5, 1.6, 0.083 , and $99.2 \mathrm{MJ} / \mathrm{kg}$ [32]. OPC and GGBS discharge 0.913 tons and 0.067 tons of $\mathrm{CO}_{2}$ per ton of production, respectively [33]. Analyses findings show that producing $1 \mathrm{~m}^{3}$ of pervious concrete $(\mathrm{C} / 10 / 10)$ emits $188.7 \mathrm{~kg}$ of $\mathrm{CO}_{2}$ and consumes $1519.5 \mathrm{MJ}$ of energy. In comparison, the use of OPC as the sole cementitious material used (Ref-OPC) results in carbon emissions of $383.6 \mathrm{~kg} / \mathrm{m}^{3}$ with an embodied energy of $2310.6 \mathrm{MJ} / \mathrm{m}^{3}$. The incorporation of GGBS in the mix reduced the embodied $\mathrm{CO}_{2}$ and energy by $51 \%$ and $34 \%$, respectively.

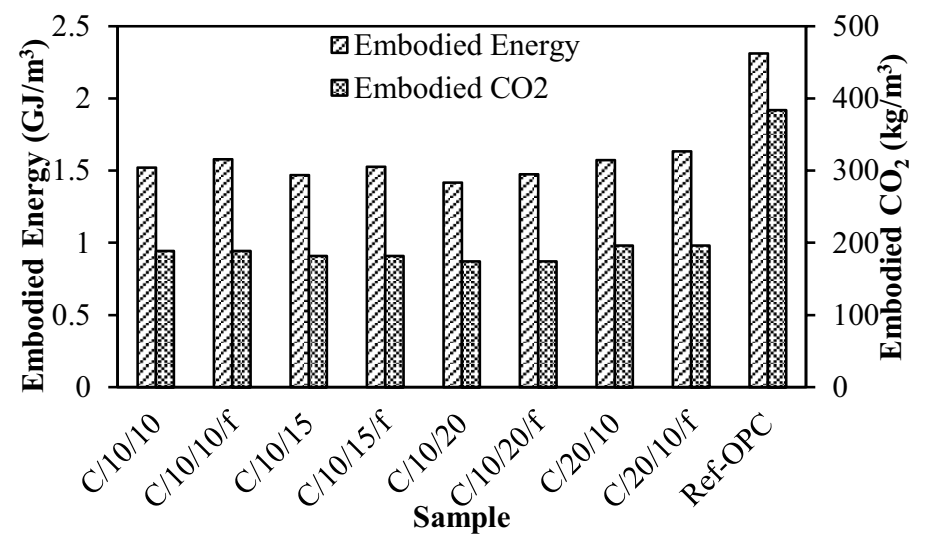

Fig. 7. Embodied Energy and carbon footprint of concrete mixes.

\section{Conclusions}

The applicability of employing pervious concrete pavement made with cement and GGBS (1:1) was investigated. The mechanical and transport properties and environmental impact were studied. Based on the findings of this study, the following conclusions may be drawn:

(1) A decrease in the porosity of cast concrete resulted in an increase in mechanical performance. Concretes made with larger aggregates $(20 \mathrm{~mm})$ exhibited higher compressive strength compared to those made with $10 \mathrm{~mm}$. Both findings owed to higher cementitious material content, thus producing a denser concrete with more hydration products. The compressive strength of low porosity concrete $(10 \%)$ was improved with the addition of fibers, but the tensile strength was unaffected.

(2) The concrete permeability was characterized by its coefficient, k. Results showed a higher permeability with higher porosity. The optimum concrete mix with $10 \mathrm{~mm}$ aggregates and $20 \%$ porosity could drain $450 \mathrm{~L}$ of water per minute over a surface area of $1 \mathrm{~m}^{2}$. It was apparent that the use of $20-\mathrm{mm}$ aggregates could reduce the permeability owing to a denser concrete with higher cementitious material content.

(3) A 40-year dust exposure showed a consistent decrease in permeability. A maintenance process was proposed to flush the concrete with water during its service life. It proved the recyclability of such concretes by restoring $67 \%$ of the initial permeability.

(4) The use of GGBS as 50\% cement replacement increased the albedo value to 0.52 compared to 0.40 and 0.10 for OPC concrete and asphalt, respectively. This would decrease the heat island effect as well as reduce electricity demand and lighting costs for paved roadways. Concrete with $10 \mathrm{~mm}$ aggregates and $20 \%$ porosity $(\mathrm{C} / 10 / 20)$ required the least amounts of cement and GGBS. Compared to OPC concrete, the associated 
carbon emissions of the least produced concrete were $55 \%$ less. The use of fibers could not be advocated given the increase in embodied energy with minor improvement in mechanical properties.

\section{References}

1. EPA. Reducing urban heat islands: compendium of strategies. USA: United States Environment Protection Agency, (2008).

2. Lee M-G, Huang Y-S, Chang T-K, Pao C-H, editors. Experimental Study of Pervious Concrete Pavement. Emerging Technologies for Material, Design, Rehabilitation, and Inspection of Roadway Pavements; (2011); Hunan, China: ASCE.

3. Ashley E. Environmental and Cost Benefits of High Albedo Concrete. Concrete in focus. (2008):2.

4. ACI Commitee 522. Pervious Concrete: Report No. 522R-10. American Concrete Institute: American Concrete Institute, (2010).

5. El-Hassan H, Kianmehr P. Pervious concrete pavement incorporating GGBS to alleviate pavement runoff and improve urban sustainability. Road Materials and Pavement Design. (2016):1-15.

6. Spark W. Historical Weather for 2012 in Dubai, United Arab Emirates United States of American: Cedar Lake Ventures, Inc; (2012) [cited 2014].

7. Carroll L. One dead amid flooding and traffic chaos after heavy rains in UAE. The National UAE. (2014).

8. Shahbandari S. Traffic congestion costs more than Dh700,000 per kilometre in Dubai. Gulf News. (2015).

9. Ferguson BK. Porous Pavements. United States of America: Taylor \& Francis; (2005). $600 \mathrm{p}$.

10. Chindaprasirt P, Hatanaka S, Chareerat T, Mishima N, Yuasa Y. Cement paste characteristics and porous concrete properties. Constr Build Mater. (2008);22(5):894901.

11. Sullivan EJ, Moss A. Paving Cost Comparisons: Warm-Mix Asphalt Versus Concrete. USA: Portland Cement Association, (2014).

12. Gadja JW, VanGeem MG. A Comparison of Six Environmental Impacts of Portland Cement Concrete and Asphalt Cement Concrete Pavements. USA: Portland Cement Association, (2001) Contract No.: PCA R\&D Serial No. 2068.

13. Taylor GW, Farrell P, Woodside A. Additional Analysis of the Effect of Pavement Structures on Truck Fuel Consumption. Canada: Government of Canada, (2002).

14. Taylor GW, Patten JD. Effects of Pavement Structure on Vehicle Fuel Consumption Phase III. Canada: National Research Council Canada, (2006) Contract No.: CSTTHVC-TR-068.

15. Athena Institute. A Life Cycle Perspective on Concrete and Asphalt Roadways: Embodied Primary Energy And Global Warming Potential. USA: Cement Association of Canada, (2006).

16. Hesami S, Ahmadi S, Nematzadeh M. Effects of rice husk ash and fiber on mechanical properties of pervious concrete pavement. Constr Build Mater. (2014);53:680-91.

17. ASTM. Standard Test Method for Sieve Analysis of Fine and Coarse Aggregates. C136. USA: ASTM International; (2014).

18. ASTM. Standard Practice for Making and Curing Concrete Test Specimens in the Laboratory. C192. USA: ASTM; (2015).

19. Montes F, Valavala S, Haselbach LM. New test method for porosity measurements of Portland cement pervious concrete. Journal of ASTM International. (2005);2(1). 
20. Ćosića K, Koratb L, Ducmanb V, Netingera I. Influence of aggregate type and size on properties of pervious concrete. Constr Build Mater. (2015);78:69-76.

21. ASTM. Standard Test Method for Compressive Strength of Cylindrical Concrete Specimens. C39. USA: ASTM; (2015).

22. ASTM. Standard Test Method for Splitting Tensile Strength of Cylindrical Concrete Specimens. C496. USA: ASTM; (2011).

23. Hall C, Hoff WD. Water Transport in Brick, Stone and Concrete USA: Taylor \& Francis; (2011).

24. Das B. Principles of Geotechnical Engineering. 7 ed: Cengage Learning; (2009).

25. Coughlin JP, Campbell CD, Mays DC. Infiltration and Clogging by Sand and Clay in a Pervious Concrete Pavement System. J Hydrol Eng. (2012);17(1):68-73.

26. Hamza W, Enan MR, Al-Hassini H, Stuut J-B, de-Beer D. Dust storms over the Arabian Gulf: a possible indicator of climate changes consequences. Aquatic Ecosystem Health \& Management. (2011);14(3):260-8.

27. Kaloush KE, Carlson JD, Golden JS, Phelan PE. The Thermal and Radiative Characteristics of Concrete Pavements in Mitigating Urban Heat Island Effects. USA: Portland Cement Association, (2008) Contract No.: PCA R\&D SN2969.

28. Virginia Department of Transportation. Road and Bridge Specifications. USA: VDOT; (2007).

29. Neithalath N. Development and characterization of acoustically efficient cementitious materials. USA: Purdue University; (2004).

30. Tegen I, Fung I. Modeling of mineral dust in the atmosphere: Sources, transport, and optical thickness. J Geophys Res. (1994);99(D11):22897-914.

31. Frey CM, Rigo G, Parlow E, editors. Investigation of the daily urban cooling island (UCI) in two coastal cities in an arid environment: Dubai and Abu Dhabi (U.A.E). 25th EARSeL Symposium Global Developments in Environmental Earth Observation from Space; (2005); Porto, Portugal.

32. Hammond G, Jones C. Inventory of Carbon \& Energy (ICE) Version 2.0 United Kingdom: University of Bath, (2011).

33. MPA Cement. Embodied CO2e of UK cement, additions and cementitious material. United Kingdom: MPA Cement, (2015) Contract No.: ST/FS/18. 